still confined to Bohr's model and Heisenberg's principle. The debt which psychology owes to Köhler had already been a large one before he investigated figural after-effects; his work in this field has almost certainly made him one of the greatest figures in psychology. It is curious and a little piquant to realize that the concepts which Köhler uses to account for figural after-effects are similar in many ways to those used by Pavlov to account for the facts of conditioning. That this should be so, in spite of the fact that not so very long ago Köhler and his colleagues founded the Gestalt school as an express antithesis to Pavlov's 'atomistic' and associationistic theorizing, illustrates the relative unimportance of the critical parts of the contribution made by schools in psychology, and the much greater importance of their positive and experimental contributions. We have fortunately now left behind to a large extent this era of rivalling schools. and it is fortunate that Köhler survived into and indeed partly originated this new period. The reader interested in the history of science can do no better than read through Dr. McEwen's monograph to discover both the promise of the present situation and also the severe birth-pains to which it is giving rise.

H. J. EYSENCK

\title{
IRON ORE IN THE SOVIET UNION
}

"T HE iron ore deposits of the Kursk magnetic anomalies, both as regards their concentration and their quality, have no rivals in the world"-so writes P. Y. Antropov, the Minister of Geology in the U.S.S.R. (Priroda, 7, 16; 1958). Magnetic anomalies were first discovered during a topographic survey in the region of Kursk in 1783 . Before the 1917 revolu. tion, E. E. Leist, professor in the University of Moscow, made a careful survey of magnetic anomalies and concluded that they are due to the presence of magnetite ores at great depths below the cover of sedimentary rocks. The results of the 1919-26 survey were rather disappointing; only rather poor iron ores were found and at a considerable depth. Renewed explorations during 1930-34 and the construction of an experimental shaft (flooded and ruined in 1938) revealed rich ore, but again at a great depth and in a very difficult geological setting. Exploration, on a much wider scale, was resumed after the Second World War. This detailed survey revealed two important features of the geological structure of this region :

(1) Below a cover, varying in thickness from 40 to $500 \mathrm{~m}$. or more, the pre-Palæozoic floor revealed a gigantic anticlinal fold, or rather a packet of such folds forming a belt about $150 \mathrm{~km} . \times 250 \mathrm{~km}$. in extent stretching in a north-west-south-east direction, with the line Orel-Kursk-Belgorod as its diagonal. This pre-Palæozoic massif was buried under a cover of Palæozoic, Mesozoic and Tertiary sedimentary rocks, and was made of Proterozoic schists, ferruginous quartzites and gneisses.

(2) The rich iron ore was not found among the Proterozoic ferruginous quartzites but in a secondary iron ore formed as a crust of weathering immediately above the Proterozoic floor. This secondary iron ore was formed through an almost complete leaching out of silica from the ferruginous quartzites and a transformation of magnetite into martite (hæmatite pseudomorphs after magnetite). The maximum thickness of this ore deposit occurs in the Belgorod district, where it reaches $350 \mathrm{~m}$. Elsewhere, it varies from 30 to $50 \mathrm{~m}$. The best-quality ore occurs in the Yakovlevsky district, where it contains on average iron 61.4 per cent, silicon 5 per cent, sulphur 0.1 per cent and phosphorus 0.02 per cent.

The reserves of ores in the Belgorod region alone are 12 milliard tons, that is to say, five times the reserves of the Krivoy Rog iron ore deposit, until now the largest known in the U.S.S.R. The total reserves of the iron ores in the region of the 'Kursk magnetic anomalies' may be as high as 15-20 milliard tons.

The winning of these ores has already begun by means of shafts and open-cast quarries in the Lebedinsky, Mikhailovsky and Yakovlevsky districts. Thus in the Lebedinsky district the open-cast extraction amounted to 6 million tons in 1956; the Mikhailovsky district is planning to extract $6 \frac{1}{2}$ million tons per annum, and the Yakovlevsky district 15 million tons. Thus the total production of these three districts by 1966 is estimated at $27 \frac{1}{2}$ million tons per annum. These figures suggest that the total extraction of rich iron ore in the whole region may be estimated at 70-80 million tons per annum. This amount of ore would correspond to $30-35$ million tons of cast iron per annum.

In this connexion it is important to note that in 1957 the total production of iron ore in the Soviet Union was $84 \cdot 2$ million tons and the total production of cast iron 37 million tons per annum.

S. I. TOMEETEFF

\section{EMPLOYMENT OF SCIENTISTS AND TECHNOLOGISTS IN THE UNITED STATES}

CCORDING to a preliminary report from the
National Science Foundation, American indus-
try in January 1957 employed 738,000 engineers and
scientists (about two-thirds of all those in the United
States), of whom 58,000 were employed as adminis-
trators of scientific and engineering activities. The
largest occupational group was 528,000 engineers,
chemists (72,000) coming next, followed by medical,
agricultural and biological scientists $(16,600)$, geo-
logists and geophysicists $(14,200)$, physicists $(12,100)$, mathematicians $(12,400)$ and metallurgists $(10,800)$. Of the total, 92,900 were employed in the electrical equipment industries, 84,900 in the aircraft and parts industry, 79,200 in chemicals and allied products industries, 74,100 in machinery, 50,700 in petroleum products and extraction, 30,200 in fabricated metal products and ordnance, 29,500 in primary metals, and 24,600 in the professional and scientific instru. ments industry ; 29,000 more chemists were employed in chemical industry than in any other industry. 